\title{
Changing patterns of habitat use by southern right whales (Eubalaena australis) on their nursery ground at Península Valdés, Argentina, and in their long-range movements
}

\author{
Victoria J. Rowntree*, Roger S. Payne ${ }^{+}$and Donald M. Schell ${ }^{\dagger}$ \\ Contacte-mail: rowntree@biology.utah.edu
}

\begin{abstract}
Southern right whales (Eubalaena australis) have been studied on their nursery ground at Península Valdés, Argentina, every year since 1970. Since 1990, 1,208 individuals have been identified from photographs taken during annual aerial surveys; 618 whales were seen in two or more years. Patterns of habitat use have changed during the study in ways which suggest that right whales may be capable of substantial behavioral and ecological flexibility. One male and three females from Península Valdés have been sighted on other nursery grounds (Tristan da Cunha and southern Brazil). Three individuals from Península Valdés were sighted on feeding grounds off Shag Rocks and South Georgia. Some right whales from Península Valdés showed carbon and nitrogen isotope ratios very similar to those seen in right whales off South Africa, while others showed distinctive isotope ratios indicating that they fed in a different area. Whales of all ages and both sexes moved frequently between three major regions of concentration on the Península Valdés nursery ground. Subadults and adult females with calves were resighted at higher rates than adult males and females in non-calf years. Changes in the geographic distribution of whales at the Península include: (1) abandonment of a major region of concentration; (2) establishment of a nursery area adjacent to the centre of a growing whalewatching industry; and (3) small-scale shifts in distribution, possibly in response to natural and human disturbances.
\end{abstract}

KEYWORDS: SOUTHERN RIGHT WHALE; BREEDING GROUNDS; FEEDING GROUNDS; SURVEY-AERIAL; DISTRIBUTION; MIGRATION; MOVEMENTS; SITE FIDELITY; SOUTH ATLANTIC

\section{INTRODUCTION}

Migratory species have large ranges that typically include several different habitat types. Individuals may vary in their use of these habitats. Such variations may be idiosyncratic or systematically related to age, sex or other characteristics of individuals. Average patterns of use may change over time for the populations as a whole. Such variations in habitat use are of interest because they influence the behavioural flexibility of the species and the interpretations of population data used in management of the species.

Southern right whales (Eubalaena australis) are distributed between $20^{\circ} \mathrm{S}$ and $60^{\circ} \mathrm{S}$ latitude and make annual migrations between higher latitudes where they feed in summer and coastal regions in lower latitudes where females calve and raise their young in the winter and spring. These migrations were documented in the previous century by whaling records (e.g. Townsend, 1935), but recent knowledge of current populations comes primarily from long-term studies of the whales on their coastal nursery grounds (e.g. Payne, 1986; Best, 1990b; Bannister et al., 1999; Bannister, 2001; Burnell, 2001; Palazzo and Flores, 1998; Patenaude and Baker, 2001). When an individual leaves the nursery ground, its probable destination is a feeding ground, but the location of current feeding grounds and the links between nursery and feeding grounds are not well understood (IWC, 2001) and are based largely on sporadic sightings of individually identified whales on feeding grounds (Goodall and Galeazzi, 1986; Ohsumi and Kasamatsu, 1986; Hamner et al., 1988; Best et al., 1993; Best, 1997; Bannister et al., 1999; Moore et al., 1999), and genetic and isotope ratio analyses of tissue samples (Best and Schell, 1996; Portway et al., 1998; Baker et al., 1999; Schaeff et al., 1999).
This paper presents evidence that right whales can be flexible in several aspects of their habitat use. The data come from a 27-year study of a population of right whales in the waters off Península Valdés, Argentina, which they use as a nursery ground. This is examined first at a large scale and then at the level of the nursery ground. Descriptions include: (1) long-range movements of individuals; (2) variation in use of the Península as individuals age or change reproductive status; and (3) changes in the overall distribution of whales at the Península, and their possible relationship to natural and human disturbances.

Right whales can be individually identified by the number, shape and location of callosities (raised patches of roughened skin) on their heads (e.g. Payne et al., 1983; Kraus et al., 1986; Best, 1990a). These callosities are covered by dense colonies of 'whale lice' (amphipod crustaceans of the family Cyamidae) whose white bodies clearly distinguish callosity tissue from intervening areas of smooth black skin (Payne et al., 1983). Since 1970, Roger Payne and his associates have used these distinctive patterns to follow the lives of known individuals on the nursery ground at Península Valdés (Payne, 1986).

Payne's study is the first systematic investigation of the right whale population at Península Valdés. During its first decade (1970s), the study documented basic features of the species' life history, such as age-at-first-reproduction and calving interval (Whitehead and Payne, 1981; Whitehead et al., 1986), and patterns of temporal and spatial distribution at the Península were noted (Payne, 1986). Although stragglers may be present throughout the year, the main group of whales begins to arrive in May or June, reaches peak numbers by the end of September or early October and most depart for the feeding grounds by December (Payne, 1986). It is not known exactly where the whales feed but three

\footnotetext{
*Whale Conservation Institute, University of Utah, Dept. of Biology, 257 South 1400 East, Salt Lake City, UT 84112, USA.

+ Whale Conservation Institute, 191 Weston Road, Lincoln, MA 01773, USA.

${ }^{\dagger}$ Institute of Marine Science, University of Alaska, Fairbanks, AK 99775, USA.
} 
individuals identified off Península Valdés have been resighted in waters near South Georgia (Best et al., 1993; Moore et al., 1999). While at the Península, the whales concentrate in distinct regions (see Fig. 1). Calves spend the first three months of their lives on the nursery ground, during which time they develop critical motor and social skills (Taber and Thomas, 1982; Thomas and Taber, 1984).

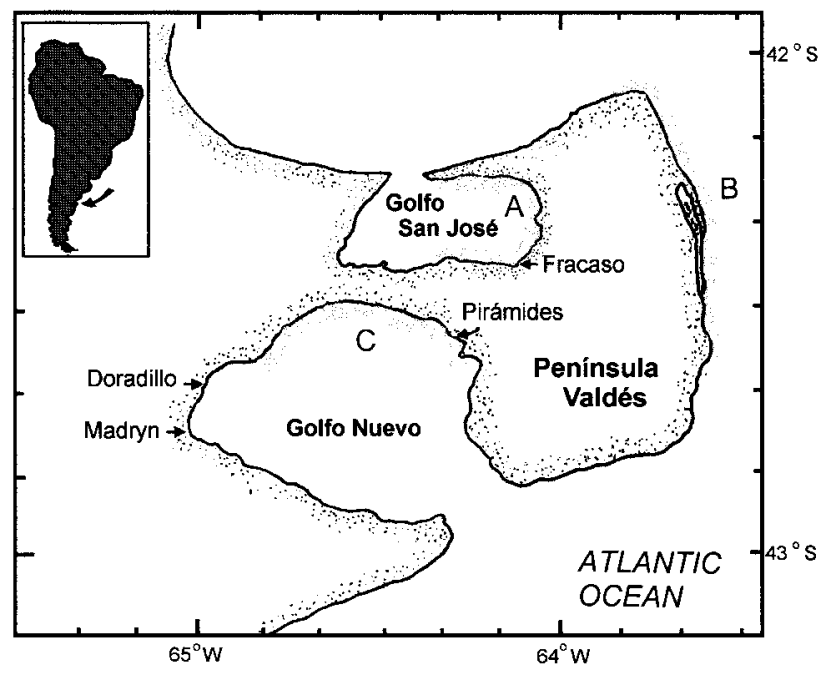

Fig. 1. Map of the southern right whale nursery grounds at Península Valdés, Argentina. Stippling indicates regions (A, B and C) where the whales concentrated between 1971-90.

In the study's second decade (1980s), the rapidly increasing number of repeat sightings was used to make improved estimates of population size and growth rate (Payne et al., 1990; Cooke et al., 2001). During this period changes in the population's spatial distribution were also noted, and Thomas (1988) documented harassment of nursing mothers by kelp gulls (Larus dominicanus). These and other developments have continued during the third decade (1990s). In several respects the population's status and behaviour have changed significantly from what seemed to be a stable pattern at the start of the study. For example, gull harassment has become much more intense and geographically widespread (Rowntree et al., 1998).

\section{METHODS}

\section{Aerial surveys}

The population of right whales at Península Valdés has been surveyed annually since 1970 , by flying along the $495 \mathrm{~km}$ perimeter of the Península in a light plane (usually a single-engine Cessna 182). From 1971 onwards, survey observers have photographed the callosity pattern of any whale encountered, noting its location, behaviour and whether it was accompanied by a calf. Survey techniques and analysis procedures are described by Payne (1986), Payne and Dorsey (1983), Payne and Rowntree (1984) and Payne et al. (1983). Survey effort has varied considerably from year to year, and was generally greater during the early years of the study (see Fig. 2), when flight time was less expensive. In those years, the same regions were surveyed repeatedly. Surveys of the entire perimeter of the Península were undertaken periodically to identify any changes in the regions where the whales concentrated. Effort varied in the number of flights per year, the timing of surveys and the specific regions of coastline surveyed. However, the purpose of each survey was to photograph as many individuals as possible so flights were consistently directed to regions where the whales were known or suspected to occur. In years with more surveys, a larger proportion of the whales present were undoubtedly photographed. In principle, such variations in effort might create spurious trends. The major quantitative changes described here are too large and too well documented to be artifacts of this kind, but variable survey effort has undobutedly caused minor systematic biases in our estimates of some parameters.

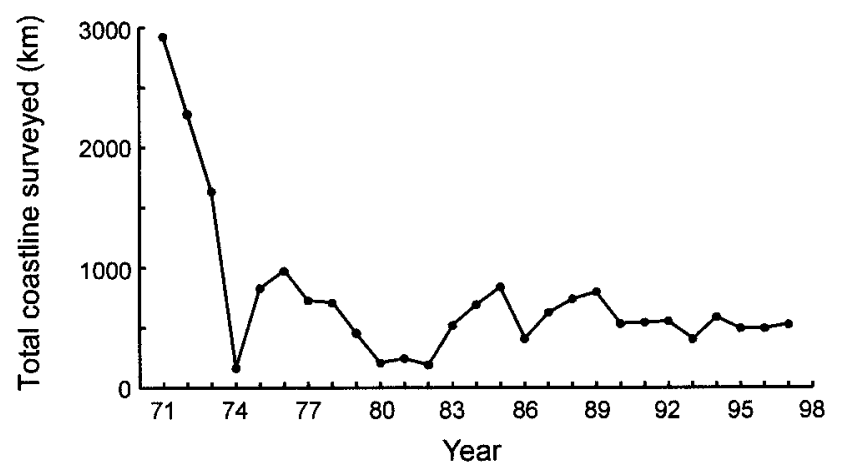

Fig. 2. Total number of kilometers of coast flown each year at Península Valdés during annual surveys of right whales.

The three regions where the whales concentrate (Fig. 1) have been surveyed each year since the study began. Surveys of the regions of concentration occurred between 15 September and 2 November with the exception of six years (1975-1977, 1982 and 1993) when these regions were surveyed either before or after those dates. Within each decade of the study there have been five or more years where surveys of the regions of concentration were conducted during the time of peak whale abundance, 15 September-15 October. This relatively complete coverage of the regions of concentration would seem to guarantee that the large-scale changes observed in these areas are real and not the result of variation in timing or the number of surveys in a region. The study is on-going and since 1991 the entire $495 \mathrm{~km}$ perimeter of the Península has been surveyed at least once each year during the time of peak whale abundance. The population has increased throughout the course of the study (Cooke et al., 2001) and the regions in which the whales concentrate have expanded. The increase in the number of whales has required more circling to photograph individuals and resulted in longer surveys. In 1971, it was possible to survey the entire Península in a day; by the 1990s, a complete survey took two to three days.

The following definitions of different age/sex categories are used in this paper: (1) subadults are whales of one to four years old that were individually identified in their calf year; (2) females are considered adults from the first year they were sighted with a calf, and are further grouped into years when they were seen with a calf and years when they were not seen with a calf (non-calf years); (3) adult males are individuals that have been morphologically sexed and do not include known-aged whales that are younger than five years. Adulthood is designated at five years of age so as to restrict the subadult category to individuals that are almost certainly immature. The mean age at first calving for southern right whales is between 8.5 and 9.1 years of age and the youngest female seen with a calf was six years old (Best et al., 2001a; IWC, 2001). A female right whale in the North Atlantic (Eubalaena glacialis) was observed with a calf when she 
was five years old (Knowlton et al., 1994). Assuming a one-year gestation period (Best, 1994), that female would have reached sexual maturity when she was four.

\section{Length of stay}

The length of time different categories of whales stay at Península Valdés was estimated by counting the number of days between a whale's first and last sightings in 1973, the year with the greatest time span between the first and last surveys (6 June to 9 December). The last surveys of the season (in December in four different years) were examined to see which age/sex categories of whales stayed the latest on the nursery ground.

\section{Long-range distribution}

Photographs of right whales from a variety of locations in the Southern Hemisphere have been examined. Whales with callosity patterns photographed in sufficient detail to determine individual identity were searched for in the catalogue of whales identified at Península Valdés. The results of these searches are described in Table 1, along with other published matches.

\section{Isotope ratio analyses}

Baleen plates were collected from seven adult and subadult whales that stranded at Península Valdés. Plates were sampled with an engraving tool at $2 \mathrm{~cm}$ intervals along their length from base to tip. Zooplankton samples were obtained from six stations using ring nets $(505 \mu \mathrm{m})$ on the continental shelf between $50-55^{\circ} \mathrm{S}$. Euphausiids and calanoid copepods were separated and dried for storage. Zooplankton were powdered prior to analysis and the carbon and nitrogen isotope ratios for all samples were then determined with a Europa 20/20 automated continuous flow isotope ratio mass spectrometry system. Average values for all samples for each baleen plate are reported in standard del notation relative to PDB (Pee Dee Belemnite) standard (carbon) and atmospheric nitrogen (nitrogen). The zooplankton and baleen data were compared with published data on Antarctic zooplankton to make the best match of the observed data with those anticipated for whales feeding in the region.

\section{Yearly resighting patterns on the nursery ground}

Use of the nursery ground by different categories of whales was examined by calculating resighting frequencies of whales seen in at least two different years at Península Valdés. Sighting frequencies were calculated for adult males, subadults and females in calf and non-calf years. A whale's first and last sightings were used to indicate that the animal was alive during the intervening years, but these were excluded from the resighting calculations. For females, this involved discarding the first and last years that they were seen with calves, to ensure that the females were reproductively active during the period being examined. Sighting frequencies for subadults were calculated for years one through four, excluding the calf year and last year the whale was seen regardless of age. For each year a whale was known to be alive, it was recorded as either having been seen or not seen.

Given that female right whales from Península Valdés usually calve once every three years (see Cooke et al., 2001), and that female right whales have never been observed to calve at a one-year interval, females could not possibly be resighted with calves in each of the 1,609 opportunities that

Table 1

Individual right whales from the Southern Hemisphere with identifying photographs that have been compared to the catalogue of right whales identified at Península Valdés $\left(42^{\circ} \mathrm{S}, 64^{\circ} \mathrm{W}\right)$ between 1971-90. Numbers in parentheses indicate whales yet to be compared to the catalogue.

\begin{tabular}{|c|c|c|c|c|c|c|c|}
\hline Location & Latitude/longitude & Date & $\begin{array}{c}\text { Whales } \\
\text { photographed }\end{array}$ & $\begin{array}{l}\text { Whales } \\
\text { ID'd }\end{array}$ & $\begin{array}{l}\text { Not enough } \\
\text { information }\end{array}$ & $\begin{array}{c}\text { No. matches } \\
\text { with Valdés } \\
\text { whales }\end{array}$ & Reference/photographer \\
\hline \multicolumn{8}{|l|}{ Nursery grounds } \\
\hline South Africa & $33-35^{\circ} \mathrm{S}, 19-21^{\circ} \mathrm{E}$ & Sep. 1974 & 47 & 24 & 23 & 0 & Best et al. 1993 \\
\hline Gough Island & $40^{\circ} \mathrm{S}, 10^{\circ} \mathrm{W}$ & 1974 & 1 & 0 & 1 & & P. Best \\
\hline Tristan da Cunha & $37^{\circ} \mathrm{S}, 12^{\circ} \mathrm{W}$ & Oct. 1989 & 2 & 2 & 0 & 1 & Best et al. 1993 \\
\hline Brazil & $28^{\circ} \mathrm{S}, 49^{\circ} \mathrm{W}$ & Sep. 1987 & 9 & 8 & 1 & 2 & Best et al. 1993 \\
\hline Brazil & $28^{\circ} \mathrm{S}, 49^{\circ} \mathrm{W}$ & Aug., Sep. 1988 & 5 & 5 & 0 & 1 & Best et al. 1993 \\
\hline Brazil & $28^{\circ} \mathrm{S}, 49^{\circ} \mathrm{W}$ & Aug. 1992 & 8 & (7) & 1 & $?$ & J.T. Palazzo \\
\hline Brazil & $28^{\circ} \mathrm{S}, 48^{\circ} \mathrm{W}$ & 1994 & 10 & $(10)$ & 0 & $?$ & J.T. Palazzo \\
\hline Brazil & $27^{\circ} \mathrm{S}, 48^{\circ} \mathrm{W}$ & Sep. 1981 & 2 & 2 & 0 & 0 & I. Camara \\
\hline Brazil & $32^{\circ} \mathrm{S}, 52^{\circ} \mathrm{W}$ & Aug. 1977 & 1 & 1 & 0 & 0 & I. Camara \\
\hline Brazil & $32^{\circ} \mathrm{S}, 52^{\circ} \mathrm{W}$ & Sep. 1994 & 1 & 0 & 1 & 0 & L. Barcellos \\
\hline Brazil & $32^{\circ} \mathrm{S}, 52^{\circ} \mathrm{W}$ & Oct. 1991 & 1 & 1 & 0 & 0 & Dantas and Siciliano \\
\hline Brazil & $23^{\circ} \mathrm{S}, 43^{\circ} \mathrm{W}$ & Sep. 1991 & 1 & 0 & 1 & 0 & S. Siciliano \\
\hline Brazil & $23^{\circ} \mathrm{S}, 52^{\circ} \mathrm{W}$ & Dec. 1992 & 1 & 1 & 0 & 0 & S. Siciliano \\
\hline Chile & $23^{\circ} \mathrm{S}, 70^{\circ} \mathrm{W}$ & Jun. 1984 & 1 & 0 & 1 & 0 & J.C. Cardenas \\
\hline Argentina & $41^{\circ} \mathrm{S}, 65^{\circ} \mathrm{W}$ & Aug. 1972 & 1 & 1 & 0 & 0 & J. Jehl \\
\hline Australian Bight & $31^{\circ} \mathrm{S}, 131^{\circ} \mathrm{E}$ & 1993 & 1 & 1 & 0 & 0 & S. Burnell \\
\hline New Zealand & $40-47^{\circ} \mathrm{S}, 165-175^{\circ} \mathrm{E}$ & 1981 & 1 & 1 & 0 & 0 & W. Doak \\
\hline New Zealand & $39^{\circ} \mathrm{S}, 174^{\circ} \mathrm{E}$ & Aug. 1982 & 1 & 1 & 0 & 0 & M. Cawthorn \\
\hline New Zealand & $47^{\circ} \mathrm{S}, 168^{\circ} \mathrm{E}$ & 1990 & 1 & 1 & 0 & 0 & A. $\operatorname{Cox}$ \\
\hline \multicolumn{8}{|l|}{ Feeding grounds } \\
\hline South Georgia & $54^{\circ} \mathrm{S}, 38^{\circ} \mathrm{W}$ & Dec. 1972 & 1 & 0 & 1 & 0 & M. Payne \\
\hline South Georgia & $54^{\circ} \mathrm{S}, 38^{\circ} \mathrm{W}$ & Apr. 1977 & 1 & 1 & 0 & 0 & F. Todd, J. Jehl \\
\hline South Georgia & $54^{\circ} \mathrm{S}, 38^{\circ} \mathrm{W}$ & Mar. 1984 & 1 & 1 & 0 & 1 & Best et al. 1993 \\
\hline South Georgia & $54^{\circ} \mathrm{S}, 38^{\circ} \mathrm{W}$ & Aug. 1989 & 1 & 0 & 1 & 0 & T. Barton \\
\hline Shag Rocks & $53^{\circ} \mathrm{S}, 41^{\circ} \mathrm{W}$ & Jan., Feb. 1997 & 20 & 12 & 8 & 2 & Moore et al. 1999 \\
\hline Antarctic & $63-64^{\circ} \mathrm{S}, 61-63^{\circ} \mathrm{W}$ & Apr. 1986 & 4 & 3 & 1 & 0 & G. Stone \\
\hline Antarctic & $60-63^{\circ} \mathrm{S}, 47-62^{\circ} \mathrm{W}$ & Jan. $1983+1984$ & 3 & 2 & 1 & 0 & Ohsumi and Kasamatsu 1986 \\
\hline Antarctic & $?$ & Mar. 1995 & 2 & 1 & 1 & 0 & M. Foucard \\
\hline Total & & & 128 & 86 & 42 & 7 & \\
\hline
\end{tabular}


occurred to see them between their first and last calf years. To derive a meaningful estimate of resighting frequencies of adult females, the number of times females with calves could have been seen with calves if they always calved at three-year intervals were counted. It was assumed that a female could not calve in the two years following her first sighting with a calf, nor in the two years preceding her last sighting with a calf.

Frequencies were calculated by dividing the number of years a whale was seen by the total number of years between its first and last sighting. Year-to-year sighting frequency is affected by the sightability of individuals. For example, females in calf years remain on the nursery ground for a long time and spend much of that time in shallow water resting at the surface. As a consequence they are easier to photograph than females in non-calf years and so are expected to have a higher resighting frequency, other things being equal.

It should be emphasised that the resighting frequencies presented here can be viewed only as relative measures and do not represent the actual return frequencies of the different categories of whales. However, because all categories received approximately the same survey effort in a year, differences among categories should reflect real differences in their behaviour such as amount of time spent at the surface, frequency of return to the nursery ground or the length of stay on the nursery ground.

\section{Movements between regions of concentration}

When the whales are at Península Valdés, they regularly occupy specific stretches of coast which are described here as 'regions of concentration'. These regions are indicated with stippling in Fig. 1. To determine whether individuals returned repeatedly to the same region of concentration on the nursery ground or moved between regions of concentration from one year to the next, the number of 'moves' and 'stays' for successive sightings of identified individuals were counted. For example, if a whale was seen in region $\mathrm{A}$ in year one and region $\mathrm{A}$ and then $\mathrm{B}$ in year two, it was scored as a 'stay' between years one and two and a 'move' within year two. 'Moves' within and between years were given equal weight. The frequency of moves between regions of concentration was calculated as the total number of moves divided by the total number of moves plus stays for different age/sex categories of individuals. Unlike the analysis of resightings, no sightings were excluded in the analyses of moves. Sightings of subadults were recorded between the calf year through age four. Sightings of adult females were recorded from the first year they were seen with a calf. Movement patterns for females were divided into two groups: movements between years that they were seen with calves and movements between years that they were not seen with calves.

In the 1980s, the whales abandoned their region of concentration along the Outer Coast of the Península and an increasing number joined the concentration in Golfo Nuevo. To gain a better understanding of this change in the whales' distribution, a year-by-year analysis of the frequency and direction of the moves of known individuals was undertaken. Analyses were undertaken to identify the year when the whales started to abandon the Outer Coast and to see whether the whales that began moving into Golfo Nuevo were the same individuals that left the Outer Coast. Only the moves of females in calf years were examined because they were the predominant category of whale seen along the Outer Coast in the 1970s and because they were the category with the most resightings. The population of right whales at Península Valdés is growing (see Cooke et al., 2001). If the tendency for females to move remains the same but the number of calving females increases as a result of population growth, then the number of moves observed would be expected to increase. To adjust for population growth, the proportion of moves among all resightings for each year of the study was examined.

\section{RESULTS}

\section{General results 1971-1990}

Between 1971 and 1990, 1,208 individual right whales were identified from photographs taken during 104 aerial surveys of Península Valdés. Among the identified whales, 340 were females, 33 were males and 252 were known-age individuals (whales identified in their calf year). Of the 1,208 identified whales, $58 \%$ were sighted on more than one aerial survey and seven were sighted on 20-23 different surveys. Half of the whales were seen in two or more years and 21 whales were seen in 9-12 different years.

\section{Length of stay on the nursery ground}

Females with calves remain significantly longer on the nursery ground than other whales $(t=3.34$, d.f. $=91$, $p=0.001)$. In 1973, females with calves stayed a mean of 77 days ( $\mathrm{SD}=36.4, n=36$, range 15-170 days) while other whales stayed 52 days ( $\mathrm{SD}=34.4, n=57$, range 8 -145 days). Of the 45 individually identified whales seen late in the season (December), 15 (33\%) were females with calves, 9 $(27 \%)$ were subadults, one $(2 \%)$ was an adult male and 16 $(36 \%)$ were whales of unknown age and sex.

\section{Long-range distribution of Península Valdés right whales}

The Península Valdés catalogue was examined for 69 whales photographed in other regions of the Southern Hemisphere (Table 1). Seven matches were found and are described below.

\section{Nursery grounds}

Four whales that were identified off Península Valdés have been photographed on other nursery grounds in the Southern Hemisphere (Table 1). A male that was seen at Península Valdés in six different years between 1971-78 was photographed 4,424km away off Tristan da Cunha in 1989 (Best et al., 1993). Three females that were photographed off Península Valdés, two with calves, were photographed in other years with calves off southern Brazil, 2,051km away (Best et al., 1993). No further matches were found for the other 45 right whales from Southern Hemisphere nursery grounds (Table 1) that were compared with the Península Valdés catalogue.

\section{Feeding grounds}

Three right whales photographed off Península Valdés (a female and two adults of unknown sex) were photographed on feeding grounds near South Georgia 2,272km to the southeast of the Península. Two of the whales were near Shag Rocks (Moore et al., 1999) and the other was off Bird Island (Best et al., 1993). None of the 17 other right whales photographically identified on Southern Hemisphere feeding grounds were found in the Península Valdés catalogue.

The average isotope ratios from seven baleen plates collected from whales that stranded at Península Valdés are shown in Fig. 3 and compared with right whale data from South Africa (Best and Schell, 1996). Four of the whales cluster within the range of isotope ratios found for whales off South Africa ( -22 to $-26 \% \circ \delta^{13} \mathrm{C}, 5$ to $\left.7 \% \circ \delta^{15} \mathrm{~N}\right)$. However, 


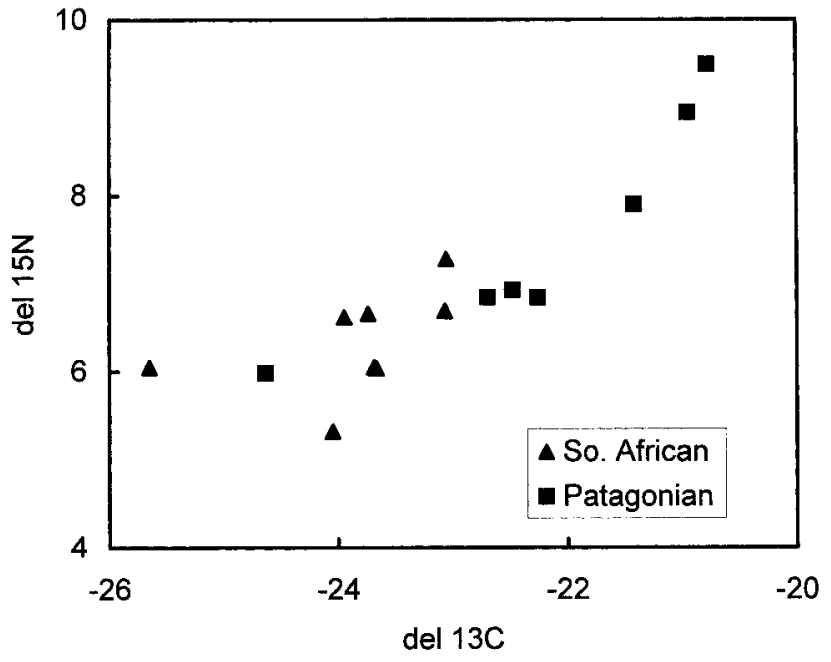

Fig. 3. Average $\delta^{13} \mathrm{C}$ and $\delta^{15} \mathrm{~N}$ values from Patagonian right whale baleen (squares) sampled at $2 \mathrm{~cm}$ intervals along the lengths. Baleen plate lengths ranged from $65-245 \mathrm{~cm}$. South African whale data (triangles) are from Best and Schell (1996).

three whales had higher $\delta^{15} \mathrm{~N}$ and $\delta^{13} \mathrm{C}$ values $(-20.5$ to $-21.5 \%$ o $\delta^{13} \mathrm{C}, 7.8$ to $10 \%$ o $\delta^{15} \mathrm{~N}$ ), indicating that their food sources were more enriched for heavy isotopes than the food of the other whales. Zooplankton samples from the continental shelf along the southern Argentine coast had copepod $\delta^{13} \mathrm{C}$ values of $-23.0,-19.1,-20.2$ and $-20.5 \%$ and $\delta^{15} \mathrm{~N}$ values of $8.4,8.8,14.6$ and $10.7 \%$. Two samples of euphausiids collected near 54-55 $\mathrm{S}$ had $\delta^{13} \mathrm{C}$ values of -18.1 and $-18.0 \%$ and $\delta^{15} \mathrm{~N}$ values of 10.5 and $12.3 \%$. The more elevated isotope ratios in these zooplankton may account for the elevated values observed in the baleen and imply that these whales consumed significant amounts of food from higher latitudes.

Table 2

Year to year resighting frequencies of different categories of right whales on the nursery ground at Península Valdés between 1971-90.

\begin{tabular}{lccc}
\hline & \multicolumn{3}{c}{ Resightings } \\
\cline { 2 - 4 } Category of whale & Possible & Actual & Frequency \\
\hline Adult males & 234 & 52 & 0.22 \\
Whales 1-4 years & 257 & 87 & 0.34 \\
Adult females & 1,609 & 368 & 0.23 \\
Assuming 3-year & & & \\
calving interval & & & \\
in calf years & 367 & 197 & 0.53 \\
in non-calf ycars & 1,242 & 171 & 0.14 \\
ycar before calf & 389 & 23 & 0.06 \\
year after calf & 386 & 41 & 0.11 \\
\hline
\end{tabular}

\section{Resightings and distribution on the Península Valdés nursery ground \\ Resighting patterns}

Resighting frequencies between years were significantly different for different categories of whales (Table 2). Subadults had the highest resighting frequency (0.34). Adult males were resighted as often as adult females $(0.22$ versus 0.23 ) when female sightings in calf and non-calf years were combined. However, adult females were seen more in calf years than in non-calf years. If females always calved at three-year intervals, then they could have been seen 367 times in calf years and 1,242 times in non-calf years. They were actually seen with calves 197/367 times for an adjusted resighting frequency of 0.53 in calf years, and without calves
$171 / 1,242$ times for an adjusted frequency of 0.14 in non-calf years; this difference is highly significant $\left(\chi^{2}=255, p=0\right)$. In years when they calved, females had the highest resighting frequency $(0.53)$ of all categories of whales. The non-calf resightings occurred significantly more often in the year after a female was seen with a calf than in the year before $\left(\chi^{2}=5.67, p=0.018\right)$.

The resighting frequency of subadults decreased with age from a high of 0.51 at age one to 0.22 at age four (Fig. 4). These known-aged whales were not dying at the rate implied by this rapid decline in their resighting frequency. Of the 92 whales that were first identified at Península Valdés in their calf year between 1971 and 1989, and that were seen in at least one other year, $59 \%$ were resighted when they were older than four years. Seventeen of the 54 known-aged whales that were resighted when they were older than four were not seen between the ages of one and four.

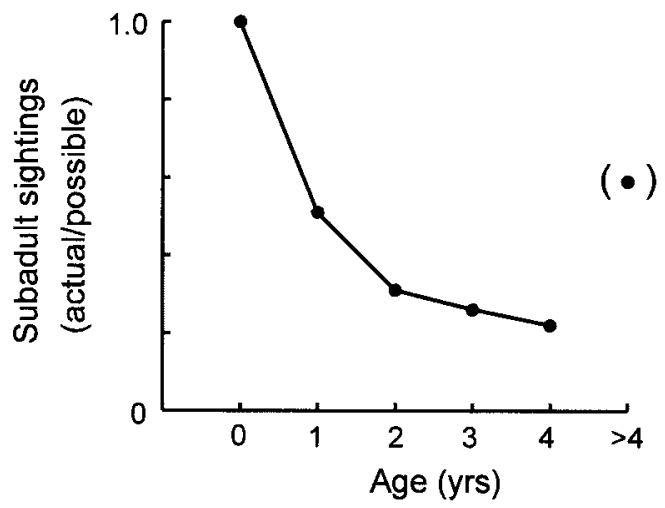

Fig. 4. Resighting frequencies of 92 subadult right whales between the ages of one and four years. Number of subadults in each year class that were sighted divided by the number of subadults in that year class known to be alive. The dot in parentheses indicates the $59 \%$ of the subadults that were seen when they were older than four.
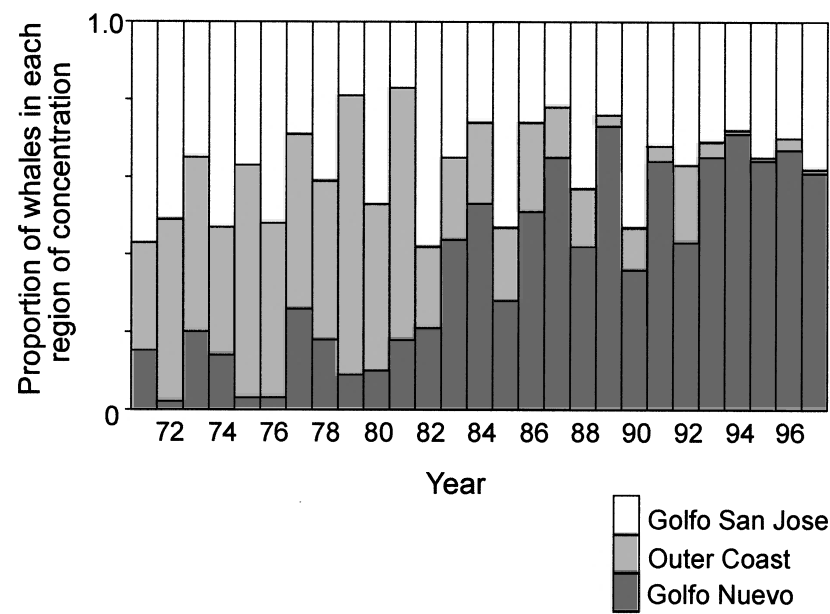

Fig. 5. Yearly distribution of right whales between the three regions of concentration at Península Valdés. Years 1971-90 are based on total number of whales individually identified. Years 1991-97 are based on total number of whales sighted.

Changes in distribution on the nursery ground

The geographical distribution of whales at Península Valdés has changed considerably between 1971 and 1997. Fig. 5 shows the yearly distribution of whales between the three regions of concentration: Golfo San Jose; the Outer Coast of the Península; and Golfo Nuevo. Data from 1971-90 are based on the number of whales individually identified in each region and data from 1991-97 are based on the number 
of whales sighted. In the early years of the study most of the whales were seen in the northern bay, Golfo San Jose, and along the Outer Coast. At that time the Outer Coast was the region of concentration with the highest proportion of females with calves (0.68) followed by Golfo San Jose (0.36) and Golfo Nuevo (0.09) (Payne, 1986). In the 1980s, the whales began abandoning the Outer Coast and establishing a new nursery ground in the southern bay, Golfo Nuevo. By the 1990s, the highest proportion of females with calves (0.63) occurred in Golfo Nuevo and few whales were seen along the Outer Coast.

The changes in use of the different regions are shown in greater geographic detail in Fig. 6, which depicts the overall sighting rate per kilometer of survey coverage for each $5 \mathrm{~km}$ segment of coastline, separately for each of the three decades of the study. Few whales were sighted along the Outer Coast in the 1990s despite complete surveys of the coast each year and the greatest number of whales was recorded in Golfo Nuevo. Within the regions of concentration, the particular segments of coast with the most whales have also changed. In the 1970s in Golfo San Jose, the 5km strip with the most whales was between kilometers 65-70 (Fracaso), but in the 1990s it was between kilometers 85-90. In Golfo Nuevo, the $5 \mathrm{~km}$ strip with the most whales has remained between kilometers 340-350, but the number of whales in Golfo Nuevo has increased in the 1990s and the area in which they are concentrating has extended to include kilometers $370-425$.

A subgroup of females that calved in Golfo Nuevo in 1994 and 1997 has shifted its region of concentration. In 1994, the concentration of these females with calves was near Playa Doradillo (kms 405-410), 50 kilometers to the west of the usual concentration of mother-calf pairs and the centre of the whalewatching industry in Piramides (see Figs 1 and 6). Three years later, in 1997, the females returned with their calves to the same area near Playa Doradillo.

\section{Movements between regions of concentration}

All age/sex categories of whales were seen to move between the regions of concentration at the Península ( 0.53 of all adult resightings involved moves). Only a small proportion of resightings $(53 / 787$ or $7 \%)$ were within-year moves, so most moves came from individuals returning to different regions of concentration in subsequent years. Some age/sex categories of whales moved significantly more than others (Table 3). Females in calf years and subadults were indistinguishable in their frequency of moves between successive sightings ( 0.48 and 0.45 respectively, $\chi^{2}=0.52$, $p=0.47$ ). Likewise, females in non-calf years and males were indistinguishable in their frequency of moves $(0.56$ and 0.60 respectively, $\left.\chi^{2}=0.52, p=0.47\right)$. But females in non-calf years and males moved significantly more than females in calf years and subadults $\left(\chi^{2}=4.02-5.30\right.$, $p=0.04-0.02$ for all possible comparisons). The differences in frequency of moves for different categories of adult whales was the same in the 1970s and 1980s, but all categories of adult whales moved significantly more in the 1980s (Table 3). There were too few sightings of subadults in the 1980s to include them in the analyses and the results from the 1990s are still being analysed.

Table 3

Movement frequencies of right whales between the regions of concentration on the nursery ground at Península Valdés. The frequency of moves $=$ the number of moves in successive sightings divided by the total number of suceessive sightings for that category (in parentheses).

\begin{tabular}{|c|c|c|c|c|}
\hline & \multicolumn{4}{|c|}{ Frequency of moves } \\
\hline & All data & $1970 \mathrm{~s}$ & $1980 \mathrm{~s}$ & $\begin{array}{l}\text { Significance } \\
1970 \text { s vs } 1980 \mathrm{~s}\end{array}$ \\
\hline All adults & $0.53(785)$ & $0.48(377)$ & $0.57(408)$ & $\mathrm{p}=0.009$ \\
\hline $\begin{array}{l}\text { Females in } \\
\text { calf years }\end{array}$ & $0.48(409)$ & $0.36(122)$ & $0.54(287)$ & $\mathrm{p}=0.001$ \\
\hline $\begin{array}{l}\text { Whales } \\
1-4 \text { years }\end{array}$ & $0.45(135)$ & & & \\
\hline $\begin{array}{l}\text { Females in } \\
\text { non-calf years }\end{array}$ & $0.56(285)$ & $0.53(195)$ & $0.62(90)$ & $\mathrm{NS} p=0.160$ \\
\hline Adult males & $0.60(91)$ & $0.53(60)$ & $0.74(31)$ & $\mathrm{p}=0.054$ \\
\hline
\end{tabular}

Fig. 7 shows the proportion of moves in the resightings of females with calves from 1971 through 1990. There were fewer moves between successive sightings in the 1970s than in the 1980s (Fig. 7d). There may have been a peak in moves
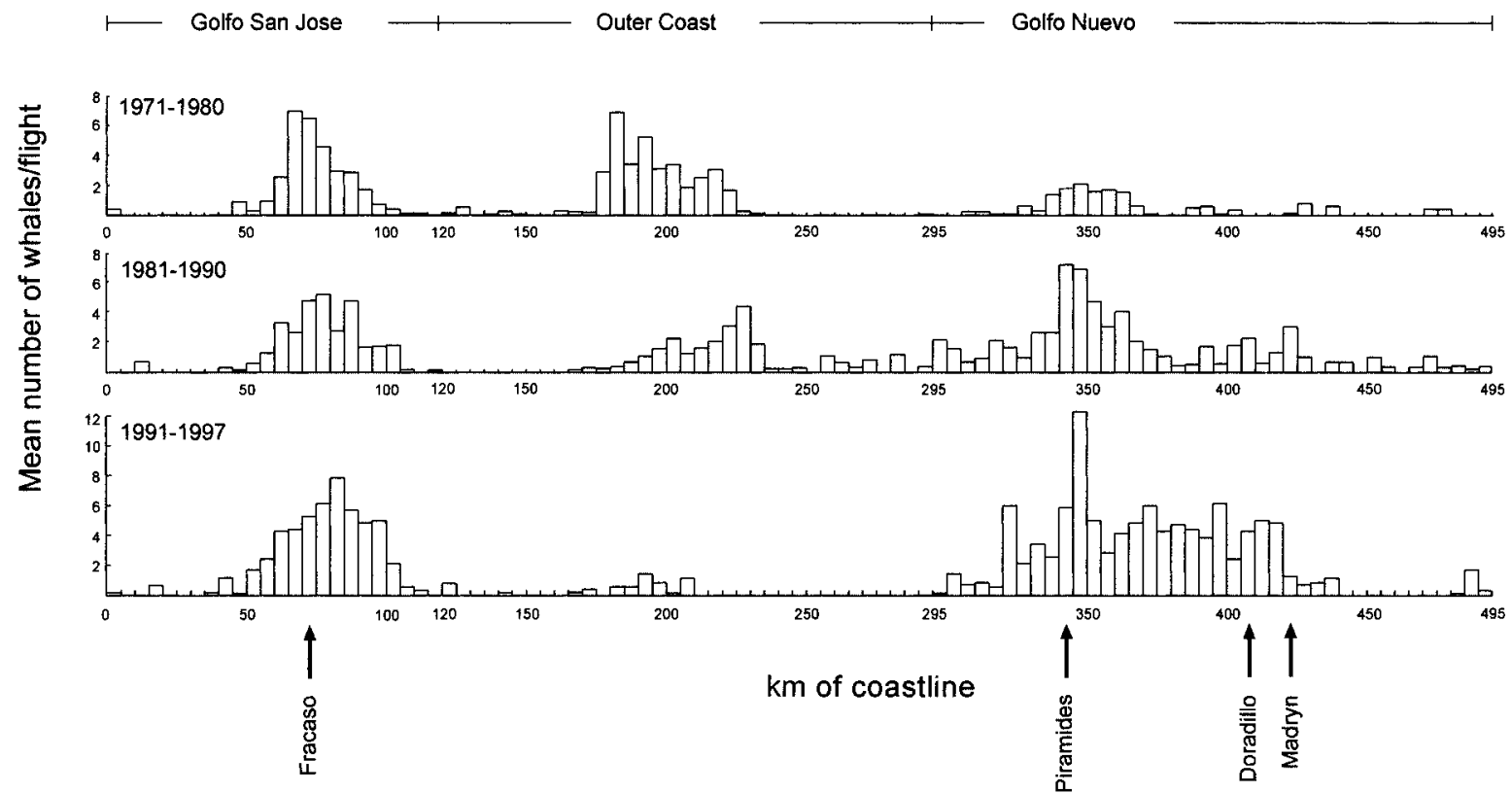

Fig. 6. Changes in the distribution of right whales by decades between 1971-97. The numbers of whales seen in each $5 \mathrm{~km}$ segment of coast is the number of whales sighted divided by the number of surveys over that segment of coastline in each decade. Kilometre 0 occurs at the western mouth of Golfo San Jose and km 495 occurs at the western mouth of Golfo Nuevo. 


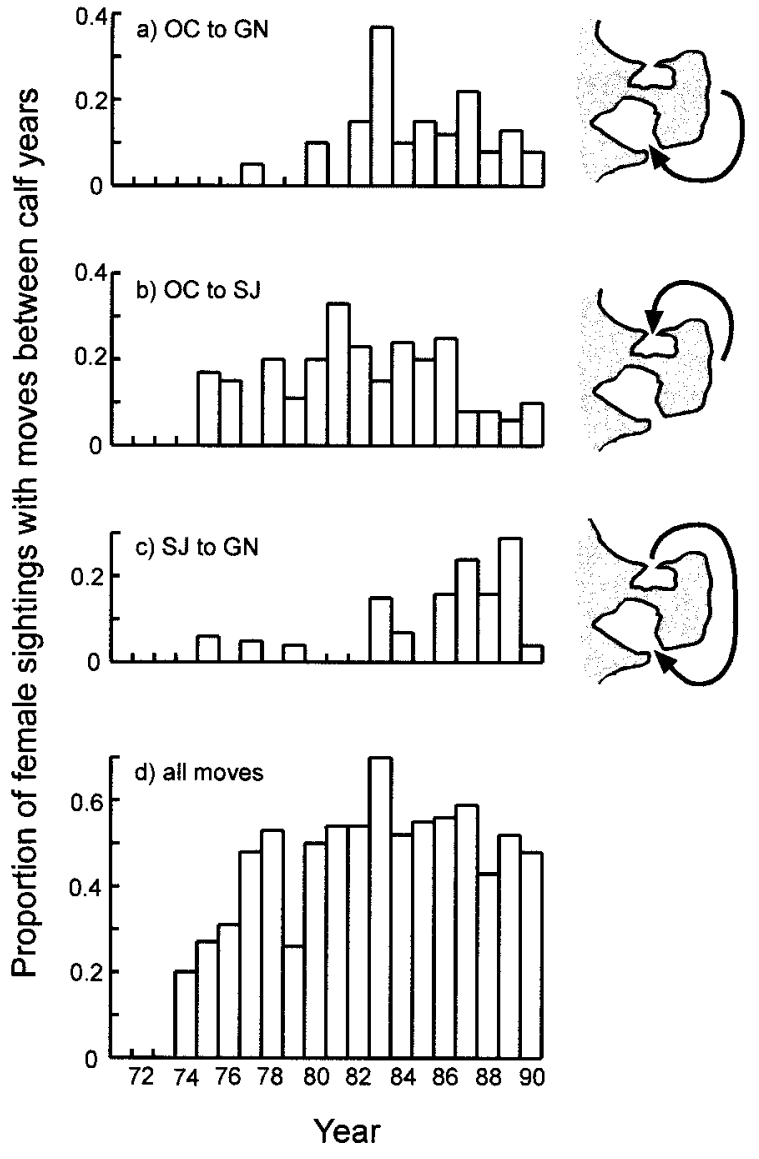

Fig. 7. Movement between the regions of concentration at Península Valdés by females in years that they calved. The proportion of moves in each year is the number of moves divided by the total number of resightings of females with calves in that year. The direction of the most frequently seen moves are shown in 7(a) Outer Coast to Golfo Nuevo, 7(b) Outer Coast to Golfo San Jose, and 7(c) Golfo San Jose to Golfo Nuevo.

in 1983, indicating that an event around that time may have caused the whales to abandon the area. Unfortunately, 1980, 1981 and 1982 were years with poor survey coverage so we cannot be sure that the moves in those years are representative.

There were six possible moves that females could have made between the regions of concentration. Figs $7 \mathrm{a}, 7 \mathrm{~b}$ and $7 \mathrm{c}$ show the distribution of the most frequently seen moves (22\% from the Outer Coast into Golfo Nuevo, 26\% from the Outer Coast into Golfo San Jose and 20\% from Golfo San Jose into Golfo Nuevo). Fig. 7a shows a peak in movement from the Outer Coast into Golfo Nuevo in 1983 and a steady movement in that direction in the years that followed. Fig. $7 b$ shows a steady movement from the Outer Coast into Golfo San Jose across all years of the study but with a peak in moves in 1981 which again could be an artifact of the poor survey coverage in that year. There is a steady increase in moves from the Outer Coast into Golfo San Jose from 1975-86 and then a sharp decline in moves in this direction. Fig. 7c shows that females in calf years began increasing their moves from Golfo San Jose into Golfo Nuevo in the late 1980s. These data indicate that females in their calf years do not appear to be faithful to a particular region of concentration on the nursery ground and that something caused the majority of the moves in the 1980s to be either from the Outer Coast into Golfo San Jose (25\%), or from the Outer Coast into Golfo Nuevo (27\%). From 1986-90 there appeared to be a movement of females from Golfo San Jose into Golfo Nuevo such that $76 \%$ of all moves in that direction (during the 20 years between 1971-90) occurred during that period of five years.

\section{Problems that could affect the recovery of the Península Valdés right whales}

Scars provide evidence of previous injuries. The most prevalent scars on the right whales at Península Valdés are $5-20 \mathrm{~cm}$ lesions caused by kelp gulls which have learned to feed on skin and blubber that they gouge from the whales' backs (Rowntree et al., 1998). Kelp gulls were first observed feeding in this manner around 1979 (R. Payne and R. Bastida, pers. obs.). In 1990, 32\% of the whales had lesions on their backs that could be attributed to gull attacks (Rowntree et al., 1998). The gull attack problem continues to escalate. In 1984, gulls rarely attacked calves (Thomas, 1988) but by 1997, most of the calves in the Golfo San Jose study area had a series of gull-induced lesions along their spines. The frequency of gull attacks in the study area almost doubled between 1995 and 1997, from 12\% to $20 \%$ of the intervals the whales were under observation (Rowntree et al., 1998; VJR, M. Lanfiutti, M. Failla and G. Ruiz unpublished data).

The frequency of gull attacks is not the same in all regions of the Península. In 1995, data were collected from three different sites around the Península. The number of gull attacks in Fracaso (kilometers 70-80) was three times higher than at the two other sites (Rowntree et al., 1998). Research by Thomas (1988) indicates that the kelp gull attack behaviour may have originated in Fracaso. In the 1970s this broad, gradually sloping, sandy bottomed beach was a preferred area for whales; but by the 1980s the segment of coast with the highest number of whales shifted several headlands away from Fracaso, and this shift continued into the 1990s (Fig. 6). It is not known whether this movement was driven by gull attacks, but it was a movement away from the site with the highest frequency of gull attacks. However, whales with lesions do not appear to be more likely to move than whales without lesions. In the 1980 s, $47 \%$ of 91 whales with lesions moved between successive sightings, compared to $57 \%$ of 137 whales without lesions $\left(\chi^{2}=2.06, p=0.15\right)$. In 1997, gull harassment was so widespread at Península Valdés that there appeared to be no area in which the whales were free from attacks.

Thirty-two whales were photographed at Península Valdés (2.6\% of identified whales) with scars from injuries not caused by gulls. Ten whales had large, long-lasting wounds, ranging from round openings to long open gashes. One calf survived for at least one year with most of its fluke-tips cut off. Eight whales have regularly spaced slash marks that appear to be propeller scars from small boats. These scars were first seen in 1982. Seven whales have long, thin gashes generally oriented along the length of the whale's body. Five whales have smaller wounds on their bodies or nicks along their tailstocks. Two whales have white jagged wounds on the surfaces of their flukes, from which hang loose flaps of skin. While observing whales from shore parallel scars have been seen which by their placement, spacing and number must have resulted from bites by killer whales (Orcinus orca). Stranded calves with killer whale tooth scars have also been found. However, these bite marks are small and difficult to document in photographs taken from an airplane. One female with a rope threaded through her baleen has also been seen. 


\section{DISCUSSION}

\section{Long-range distribution}

Genetic analyses of mitochondrial control region sequences from right whales off South Africa and Península Valdés found 32 polymorphic sites that yielded 23 haplotypes (Portway et al., 1998). Three of these haplotypes were found on both nursery grounds (South Africa and Península Valdés), while the remaining 20 haplotypes were unique to one nursery ground or the other. The distribution of haplotype frequencies for the two nursery grounds differed significantly and quantitative estimates of genetic differentiation suggest that for purposes of management and conservation, the right whales off Península Valdés and South Africa should be considered to represent genetically distinct populations (Portway et al., 1998). Different levels of expression of white and gray skin pigmentation in the two nursery grounds (Best, 1981; 1990a; Payne et al., 1983; Schaeff et al., 1999) provide additional evidence that the whales using the two nursery grounds are genetically differentiated. Sightings data also indicate a separation of the nursery grounds. Twenty-four whales identified off South Africa in 1974 had not appeared in the Península Valdés catalogue as of 1990 (Table 1).

However, low levels of gene flow could occur between nursery grounds. A male that was seen over an eight year period at Península Valdés was photographed later off Tristan da Cunha in the central South Atlantic (Best et al., 1993), a region that appears to be a nursery ground (Best, 1988). A female right whale photographed off nearby Gough Island $\left(40^{\circ} \mathrm{S}, 9^{\circ} \mathrm{W}\right)$ was photographed five years later off South Africa with a calf (Best et al., 1993), suggesting a link between Gough Island and South Africa.

Right whale females show flexibility in their use of nursery grounds. Two females that had calves at Península Valdés were seen in other years with calves off southern Brazil, 2,051km away (Best et al., 1993). These sightings indicate either that females may move between nursery grounds in the year their calves are born, or they may use different nursery grounds in different years.

Resightings of three whales from Península Valdés on the feeding grounds near South Georgia indicate that these waters are one migratory destination for the whales calving at Península Valdés. Genetic analyses of tissue samples collected from whales on the feeding grounds near South Georgia revealed 10 haplotypes but the sample size was too small to permit a test of population differentiation (Schaeff, pers. comm.).

Isotope ratio data suggest that at least a portion of the whales from Península Valdés feed south of the Polar Front and in regions where the bulk of the prey species have carbon and nitrogen isotope ratios similar to the prey consumed by South African whales (Best and Schell, 1996). Baleen from three of the Península Valdés whales indicated that they fed in another region where their prey were more enriched for heavy isotopes. Six samples of copepods and euphausiids collected from continental shelf waters between $50-55^{\circ} \mathrm{S}$ had $\delta^{13} \mathrm{C}$ and $\delta^{15} \mathrm{~N}$ values that averaged $-19.9 \%$ and $10.9 \%$ respectively. Schell et al. (1989) found that bowhead whales (Balaena mysticetus) had baleen carbon isotope ratios that averaged $1.1 \%$ more enriched than muscle tissue which closely approximated diet. The $\delta^{15} \mathrm{~N}$ values for bowheads were enriched by approximately $3 \%$ relative to diet. If right whales have similar isotopic fractionation, then the zooplankton diet would be expected to have $\delta^{13} \mathrm{C}$ values near $-23 \%$ and $\delta^{15} \mathrm{~N}$ values near $4-6 \%$ instead of the $-19.9 \%$ and $10.9 \%$ reported above for the continental shelf. These expected values are more enriched in the heavy isotopes than the values reported by Rau et al. (1991a) for copepods and euphausiids from the Weddell Sea $\left(-28 \% \delta^{13} \mathrm{C}, 2.6 \% \delta^{15} \mathrm{~N}\right)$ but consistent with Drake Passage data $(-25.5$ to $-30.3 \%$ $\delta^{13} \mathrm{C}$ for particulate organic matter) also reported by Rau et al. (1991b). The average isotopic difference between copepods and euphausiids is only about $1.5 \%$ in the same environment (Schell, 1992) and cannot account for the observations assuming different whales ate solely euphausiids or copepods. Similarly, Schell (1992) found no significant isotope ratio differences in the various life stages of both copepods and euphausiids at a location. In contrast, the invertebrate samples from the Argentine coast ( -18.0 to $-23.0 \% \delta^{13} \mathrm{C}, 8.4-14.6 \% \delta^{15} \mathrm{~N}$ ) were more enriched than the whales, also indicating that the primary source of food was located south of $55^{\circ} \mathrm{S}$. This conclusion should be regarded as tentative, however, owing to the small number of samples analysed to date.

More sighting, genetic and isotope data are needed to determine the primary feeding grounds of the different Southern Hemisphere right whale populations, and to determine whether different populations share the feeding grounds. It is also important that a comparison be made between the 1,208 whales photographed off Península Valdés and other individual right whales in the catalogues of other Southern Hemisphere researchers. Newly developed software for computer-assisted matching of right whale callosity patterns will greatly facilitate these comparisons (Burnell and Shanahan, 2001; Hiby and Lovell, 2001).

\section{Patterns of use of the nursery ground by different categories of whales}

The name 'nursery ground' indicates the importance of such a region for females with young calves. Similarities in the resighting patterns at Península Valdés of females in their calf years and subadults (one to four years old) suggest that the nursery ground may be as important to subadults as it is to calving females or at least that both categories of whales have similar residency times. Female right whales with calves stay significantly longer on the nursery ground at the Península (77 days) than other categories of whales, and along with subadults are among the last animals to leave the area. Females in calf years and subadults have significantly higher resighting frequencies than females in non-calf years and males (Table 2). For subadults to have resighting frequencies similar to females with calves, they must spend a long time at the Península (indicated by their sightings late in the season) and they must spend much of their time in places and activities that make them easy to photograph, i.e. close to shore and/or at the surface. Males may have a low resighting frequency compared to subadults and females in calf years (Table 2) but they are, nevertheless, regularly sighted on Southern Hemisphere nursery grounds (Table 2; Burnell and Bryden, 1997; Schaeff and Best, 1998), unlike male right whales in the North Atlantic where only one adult male was identified among 96 adults ( 91 females, 4 whales of unknown sex) over a thirteen year period on the right whale calving/nursery ground off the southeastern United States (Kraus et al., 1993).

One-year-old calves were resighted at the Península as often as females in their calf years $(0.51$ and 0.53 of possible resightings, respectively) indicating that many subadults return to the nursery grounds at one year of age. Thomas and Taber (1984) observed females abandoning their yearling calves on the Valdés nursery ground. Studies of mother-calf pairs show that weaning can take place when whales are 
eight months old, but more typically occurs when they are about a year old (range 8-17 months; Hamilton et al., 1995; Burnell, 2001). Although mothers may bring their yearling calves back to the nursery ground, two to four year old subadults have not been observed in close proximity to their mothers, which suggests that older subadults return independently of their mothers. While the subadults are on the nursery ground their comparatively high resighting frequency indicates that they spend time in ways that give them a similar sightability to females with calves and a different sightability to females in non-calf years.

Although all categories of whales moved between the regions of concentration, females in calf years and subadults were indistinguishable in their frequency of moves and moved significantly less than males and females in non-calf years (Table 3). Female right whales with calves on the nursery ground off the Head of the Bight in Australia also show a greater fidelity to the aggregation area than unaccompanied whales, while males showed significantly less site fidelity than calving females, non-calving females or juveniles (Burnell, 2001). Calving right whales off South Africa show variable sight fidelity (ranging from $0-74 \%$ ) with the highest fidelity in the area with the most whales (Best, 1990b).

Similarities in the frequency of resightings and frequency of moves of different categories of whales at Península Valdés may indicate similar ways of using the nursery ground. If this is true our results suggest that subadults and females with calves use the nursery ground in a similar but different way from males and females in non-calf years.

\section{Changes in distribution at Península Valdés}

The change in the distribution of whales at Península Valdés between the 1970s and 1980s was not simply a movement of calving females from the Outer Coast into Golfo Nuevo. When the calving females abandoned the Outer Coast they appeared to move with equal frequencies into the northern (Golfo San Jose) and southern (Golfo Nuevo) bays of the Península. In addition, calving females appeared to begin moving from the northern gulf into the southern gulf in the late 1980s. This is a surprising result since during the same period human activities (shipping, recreational boating, fishing and whalewatching) were developing far faster in the southern gulf than in the northern gulf where all of these activities, with the exception of fishing, were inhibited in their expansion by laws declaring Golfo San Jose a sanctuary.

Changes in distribution have been noted in other right whale nursery grounds. Between the 1970s and 1980s, right whales off South Africa appeared to expand their range up the west coast and to shift the location of some regions of peak density (Best, 1990b). These shifts in regions of peak density are similar to shifts observed at Península Valdés (Fig. 6).

\section{Problems that could affect the recovery of the Península Valdés right whales}

The wounds caused by kelp gulls do not appear to be life-threatening, but the whales' responses to gull attacks may seriously deplete the energy reserves of females and their young calves (Rowntree et al., 1998). In 1995, mother-calf pairs that were attacked increased the amount of time spent travelling at medium to fast speeds by almost four times that of mother-calf pairs that were undisturbed. Approximately $24 \%$ of a typical mother's day was spent in states of gull-induced disturbance (Rowntree et al., 1998). The increase in energy expenditure due to gull harassment comes at a time when the mothers are largely fasting. Blubber reserves accumulated to feed calves are being spent fleeing gull attacks. The movement of the whales away from the site with the highest level of gull harassment in Golfo San Jose may indicate that the gulls are driving the whales from this prime calving area.

Gull harassment probably arose when the rapidly growing gull population began to outstrip its more traditional food supply. Kelp gulls are innovative feeders (Murphy, 1936; Pierotti and Annett, 1990) and their attack behaviour appears to be learned. Juveniles take part in almost one-third of the attacks and the behaviour is spreading through the population as is indicated by the observation that attack frequencies have grown at a faster rate than the gull populations (Rowntree et al., 1998). Reducing the number of gulls by restricting their access to food resources at waste disposal sites might bring some relief to the whales.

A thriving whalewatching industry has developed around the whales that return to Golfo Nuevo each year. Despite the industry, the number of whales in the Golfo Nuevo concentration has continued to increase (Fig. 6). Studies in the late 1980s showed that the activities of the boats did not affect the swimming speeds of mother-calf pairs (Alvarez Colombo et al., 1990). Since then, the growth of the industry and interactions between the whales and boats have been studied by Rivarola et al. (2001). They found that some types of boat manoeuvers caused right whales to move away from whalewatching boats, and that when whales were scarce, the same mother-calf pairs were often subjected to repeated approaches by boats. They note that the 1994 shift of the mother-calf concentration from the centre of the whalewatching industry could be a response to disturbance. However, they also note that the right whales began using the Golfo Nuevo nursery ground in increasing numbers at the same time that the industry began its expansion and the whales centred their concentration only $5 \mathrm{~km}$ from the industry's base in Piramides (see Figs 1 and 6).

Aside from the gull-induced lesions, only $2.6 \%$ of the 1,208 right whales identified at Península Valdés have obvious scars. This is a lower incidence of scarring than the $3-4 \%$ of mature female right whales with fishing gear entanglement scars off South Africa (Best et al., 2001b) and a much lower incidence than is observed for right whales in the western North Atlantic; from 1970-1988, 50 animals were documented to fit serious injury/mortality criteria, 26 (52\%) from entanglement and $24(48 \%)$ from ship strikes (Knowlton and Kraus, 2001). Boat-propeller scars were first seen at Valdés in 1982, indicating that some boats may be maneuvering too close to the whales. Rivarola et al. (2001) describe particular approaches by whalewatching that cause the whales to move away from them. The low incidence of scars in the Península Valdés right whales (aside from those caused by gulls), indicates that the whales are suffering a much lower level of disturbance from boats, ships and ropes than is reported for right whales in the western North Atlantic (Knowlton and Kraus, 2001).

However, off southern Brazil four right whales have recently stranded as a result of colliding with ships (two whales cut in two and two whales with long gashes from propeller blades) and nine right whales have been reported entangled in fishing gear (Lodi et al., 1996; Greig et al., 2001). Females sighted off both Península Valdés and southern Brazil indicate that some portion of the Valdés population is likely to encounter problems with fishing gear. 


\section{Flexibility in distribution}

Our 28 years of observation of individual right whales off Península Valdés show that right whales can be flexible in their choice of habitat. On a large scale, a male was seen on two different nursery grounds (off Península Valdés and off Tristan da Cunha). Two females were seen in different years with calves on two different nursery grounds (off Península Valdés and off southern Brazil). Flexibility is also apparent in use of the different regions within the nursery ground at Península Valdés. Although the whales concentrate in distinct regions of the Península, individuals moved between these regions in over half $(53 \%)$ of their successive sightings (Table 3). Females abandoned an important nursery area and established a new one with no apparent negative effect on the continued growth of the population. In 1994 and 1997, a group of females using one of the regions of concentration shifted their preferred area $50 \mathrm{~km}$ to the west.

It is unclear whether any of the observed changes in distribution can be attributed to disturbance. Whales that were scarred by gull attacks returned in subsequent years to regions where they were initially scarred. The site with the highest frequency of gull attacks is no longer a preferred area but females with calves do continue to use it. Females in the 1994/1997 calving cohort in Golfo Nuevo moved away from the centre of the whalewatching industry into bays with a high incidence of gull harassment, near Madryn, a region of the Península with the highest boat and ship traffic. The fact that females in other calving years have not moved to this area suggests that social cohesion and individual preference might be influencing the moves reported here more than disturbance.

It has been difficult to determine why the whales abandoned the Outer Coast of the Península. Major changes may have occurred in bottom topography, owing to storms that destroyed protection from the strong ocean currents that run parallel to shore. In the early 1970 s, there was a slight bulge in the coastline which created an eddy that was often occupied by right whales. The bulge eroded somewhat after 1975 and the whales shifted further south. But ultimately, it is not clear why the whales are changing their distribution on the nursery ground. A better understanding of the characteristics the whales search for in a preferred nursery ground is needed.

\section{ACKNOWLEDGEMENTS}

We thank: J. Seger, F. Adler and L. Blankman for help in data analysis; M. Brown (Center for Coastal Studies) and K. Johnson (Univeristy of Utah), C. Mayo (Center for Coastal Studies), J. Seger (University of Utah) and C. Tynan (National Marine Fisheries Service) for reviewing the manuscript; J. Atkinson, K. Marshall-Tilas and the pilots of the Aero Club of Trelew for long and difficult hours devoted to aerial surveys; B. Evans for logistical support; A. Arias, R. Benegas, F. Grosso, G. Harris, M. Rivarola, R. Schteinbarg, M. Sironi, D. Taboada, M. Tresphailhiex for their help in all aspects of our field work. We are grateful to H. Sanz and Estancia La Adela for cooperation during aerial surveys. Stable isotope analyses were done by Norma Haubenstock. Many individuals provided samples for isotope and genetic analyses: zooplankton samples were collected by Gustavo Alvarez Colombo of INIDEP. Tissue samples from stranded whales (including baleen plates) were collected by $\mathrm{M}$. Rivarola, A. Arias, A. Carribrero, R. Benegas and K. Marshall-Tilas of the Stranding Network at Península Valdés. Baleen plates were generously donated by G. Harris,
P. Sosa, Naturatur and guarda faunas at Península Valdés. We are grateful to all people listed in Table 1 who sent us photographs of right whales to compare with whales in the Península Valdés Catalogue. We also thank V. Lichtschein of Fauna y Flora Silvestres, and A. Torrejon and N. Garcia of the Organismo Provincial de Turismo for permits, and the Wildlife Conservation Society for use of the research station. We are especially grateful to Aerolineas Argentinas, the National Geographic Society, Sarah Haney, Metcalf and Eddy, Inc., Minolta Inc. and the Turner Foundation for generous financial support of this research.

\section{REFERENCES}

Alvarez Colombo, G., Arias, A.M. and Garciarena, A.D. 1990. Un possible efecto del la actividad de embarcaciones de observacion cobre la ballena franca autral (Eubalaena australis). Résumenes de la IV Reunion de Trabajo de Especialistas en Mamíferos Acuáticos de América de sur, Valdívia, Chile. p.1. [In Spanish].

Baker, C.S., Patenaude, N.J., Bannister, J.L., Robins, J. and Kato, H. 1999. Distribution and diversity of mtDNA lineages among southern right whales (Eubalaena australis) from Australia and New Zealand. Mar. Biol. 134(1):1-8.

Bannister, J. 2001. Status of southern right whales off Australia. J. Cetacean Res. Manage. (special issue) 2:103-110.

Bannister, J.L., Pastene, L.A. and Burnell, S.R. 1999. First record of movement of a southern right whale (Eubalaena australis) between warm water breeding grounds and the Antarctic Ocean, South of $60^{\circ}$ S. Mar. Mammal Sci. 15(4):1337-42.

Best, P.B. 1981. The status of right whales (Eubalaena glacialis) off South Africa, 1969-1979. Investl Rep. Div. Sea Fish. S. Afr. 123:1-44.

Best, P.B. 1988. Right whales, Eubalaena australis, at Tristan da Cunha. A clue to the 'non-recovery' of depleted stocks? Biol. Conserv. 46:23-51.

Best, P.B. 1990a. Natural markings and their use in determining calving intervals in right whales off South Africa. S. Afr. J. Zool. 25(2):114-23.

Best, P.B. 1990b. Trends in the inshore right whale population off South Africa, 1969-1987. Mar. Mammal Sci. 6(2):93-108.

Best, P.B. 1994. Seasonality of reproduction and the length of gestation in southern right whales Eubalaena australis. J. Zool., Lond. 232:175-89.

Best, P.B. 1997. Whale Watching in South Africa. The Southern Right Whale. 2nd Edn. Mammal Research Institute, University of Pretoria, Pretoria. 28pp.

Best, P.B. and Schell, D.M. 1996. Stable isotopes in southern right whale (Eubalaena australis) baleen as indicators of seasonal movements, feeding and growth. Mar. Biol. 124(4):483-94.

Best, P.B., Payne, R., Rowntree, V., Palazzo, J.T. and Both, M.D. 1993. Long-range movements of South Atlantic right whales Eubalaena australis. Mar. Mammal Sci. 9(3):227-34.

Best, P.B., Brandão, A. and Butterworth, D. 2001a. Demographic parameters of southern right whales off South Africa. J. Cetacean Res. Manage. (special issue) 2:161-169.

Best, P.B., Peddemors, V.M., Cockcroft, V.G. and Rice, N. 2001b. Mortalities of right whales and related anthropogenic factors in South African waters, 1963-1998. J. Cetacean Res. Manage. (special issue) 2:171-176.

Burnell, S.R. 2001. Aspects of the reproductive biology, movements and site fidelity of right whales off Australia. J. Cetacean Res. Manage. (special issue) 2:89-102.

Burnell, S.R. and Bryden, M.M. 1997. Coastal residence periods and reproduction timing in southern right whales (Eubalaena australis). J. Zool., Lond. 241:613-21.

Burnell, S. and Shanahan, D. 2001. A note on a prototype system for simple computer-assisted matching of individually identified southern right whales, Eubalaena australis. J. Cetacean Res. Manage. (special issue) 2:297-300.

Cooke, J.G., Rowntree, V. and Payne, R. 2001. Estimates of demographic parameters for southern right whales (Eubalaena australis) observed off Peninsula Valdés, Argentina. J. Cetacean Res. Manage. (special issue) 2:125-132.

Goodall, R.N.P. and Galeazzi, A.R. 1986. Recent sightings and strandings of southern right whales off subantarctic South America and the Antarctic Peninsula. Rep. int. Whal. Commn (special issue) 10:173-6. 
Greig, A.B., Secchi, E.R., Zerbini, A.N. and Dalla Rosa, L. 2001. Standing events of southern right whales, Eubalaena australis, in southern Brazil. J. Cetacean Res. Manage. (special issue) 2:157-160.

Hamilton, P.K., Marx, M.K. and Kraus, S.D. 1995. Weaning in North Atlantic right whales. Mar. Mammal Sci. 11(3):386-90.

Hamner, W.H., Stone, G.S. and Obst, B.S. 1988. Behavior of southern right whales, Eubalaena australis, feeding on the Antarctic krill, Euphausia superba. Fish. Bull. 86(1):143-50.

Hiby, L. and Lovell, P. 2001. A note on an automated system for matching the callosity patterns on aerial photographs of southern right whales. J. Cetacean Res. Manage. (special issue) 2:291-295.

International Whaling Commission. 2001. Report of the Workshop on the Comprehensive Assessment of Right Whales: A worldwide comparison. J. Cetacean Res. Manage. (special issue) 2:1-60.

Knowlton, A. and Kraus, S. 2001. Mortality and serious injury of northern right whales (Eubalaena glacialis) in the western North Atlantic Ocean. J. Cetacean Res. Manage. (special issue) 2:193-208.

Knowlton, A.R., Kraus, S.D. and Kenney, R.D. 1994. Reproduction in North Atlantic right whales (Eubalaena glacialis). Can. J. Zool. 72(7):1,297-305.

Kraus, S.D., Moore, K.E., Price, C.A., Crone, M.J., Watkins, W.A., Winn, H.E. and Prescott, J.H. 1986. The use of photographs to identify individual North Atlantic right whales (Eubalaena glacialis). Rep. int. Whal. Commn (special issue) 10:145-51.

Kraus, S.D., Kenney, R.D., Knowlton, A.R. and Ciano, J.N. 1993. Endangered right whales of southwestern North Atlantic. In: p.69. Final Report, Minerals Management service Contract No. 14-35-0001-30486. Edgerton Research Laboratory, New England Aquarium, Boston, MA.

Lodi, L., Siciliano, S. and Bellini, C. 1996. Ocorrências e conservaçao de baleias-francas-do-sul, Eubalaena australis, no litoral do Brasil. Pap. Avulsos dep. Zool. (Sao Paulo) 39(17):307-328. [In Portuguese].

Moore, M.J., Berrow, S.D., Jensen, B.A., Carr, P., Sears, R., Rowntree, V.J., Payne, R. and Hamilton, P.K. 1999. Relative abundance of large whales around South Georgia (1979-1998). Mar. Mammal Sci. 15(4):1,287-302.

Murphy, R.C. 1936. Kelp gull. In: Vol. II. Oceanic Birds of South America. The American Museum of Natural History. New York. i-vii, pp.641-1,245 + 74 pls.

Ohsumi, S. and Kasamatsu, F. 1986. Recent off-shore distribution of the southern right whale in summer, Appendix. Natural marking of right whales. Rep. int. Whal. Commn (special issue) 10:185.

Palazzo, J.T. and Flores, P.A. de C. 1998. Right Whales (Eubalaena australis) in southern Brazil: A summary of current knowledge and research needs. Paper SC/M98/RW14 presented to the IWC Special Meeting of Scientific Committee towards a Comprehensive Assessment of Right Whales Worldwide, 16-25 March, Cape Town, South Africa (unpublished). 7pp. [Available from the Office of this Journal].

Patenaude, N.J. and Baker, C.S. 2001. Population status and habitat use of southern right whales in the sub-Antarctic Auckland Islands of New Zealand. J. Cetacean Res. Manage. (special issue) 2:111-116.

Payne, R. 1986. Long term behavioral studies of the southern right whale (Eubalaena australis). Rep. int. Whal. Commn (special issue) 10:161-7.

Payne, R. and Dorsey, E.M. 1983. Sexual dimorphism and aggressive use of callosities in right whales (Eubalaena australis). pp. 295-329. In: R. Payne (ed.) Communication and Behavior of Whales. AAAS Selected Symposia Series 76. Westview Press, Colorado. xii+643pp.

Payne, R. and Rowntree, V.J. 1984. Southern right whales, a photographic catalogue of individual whales seen in the waters surrounding Península Valdés, Argentina. Fundacion Alfredo Fortabat, Buenos Aires, Argentina and Whale Conservation Institute, Lincoln, MA. 19pp+55pls. (unpublished). [In English and Spanish].
Payne, R., Brazier, O., Dorsey, E.M., Perkins, J.S., Rowntree, V.J. and Titus, A. 1983. External features in southern right whales (Eubalaena australis) and their use in identifying individuals. pp. 371-445. In: R. Payne (ed.) Communication and Behavior of Whales. AAAS Selected Symposia Series 76. Westview Press, Colorado. xii+643pp.

Payne, R., Rowntree, V., Perkins, J.S., Cooke, J.G. and Lankester, K. 1990. Population size, trends and reproductive parameters of right whales (Eubalaena australis) off Peninsula Valdes, Argentina. Rep. int. Whal. Commn (special issue) 12:271-8.

Pierotti, R. and Annett, C.A. 1990. Diet and reproductive output in seabirds. Biosci. 40(8):568-74.

Portway, V.A., Schaeff, C.M., Best, P.B., Rowntree, V., Payne, R., Moore, M.J. and Hamilton, P.J. 1998. Genetic population structure of South Atlantic right whales (Eubalaena australis). Paper SC/M98/RW21 presented to the IWC Special Meeting of the Scientific Committee towards a Comprehensive Assessment of Right Whales Worldwide, 16-25 March, Cape Town, South Africa. [Available from the Office of this Journal].

Rau, G.H., Sullivan, C.W. and Gordon, L.I. 1991a. $\delta^{15} N$ and $\delta^{13} C$ in Weddell Sea invertebrates: implications for feeding diversity. Mar. Ecol. Prog. Ser. 77:1-6.

Rau, G.H., Takahashi, T., Des Marais, D.J. and Sullivan, C.W. 1991 b. Particulate organic matter $\delta^{13} \mathrm{C}$ variations across the Drake Passage. J. Geol. 96:15131-5.

Rivarola, M., Campagna, C. and Tagliorette, A. 2001. Demand-driven commercial whalewatching in Peninsula Valdes (Patagonia): conservation implications for right whales. J. Cetacean Res. Manage. (special issue) 2:145-151.

Rowntree, V.J., McGuiness, P., Marshall, K., Payne, R., Sironi, M. and Seger, J. 1998. Increased harassment of right whales (Eubalaena australis) by kelp gulls (Larus dominicanus) at Península Valdés, Argentina. Mar. Mammal Sci. 14(1):99-115.

Schaeff, C.M. and Best, P.B. 1998. Reproductive and social behaviour of right whales off South Africa: preliminary results of genetic analyses. Paper SC/M98/RW36 presented to the IWC Special Meeting of the Scientific Committee towards a Comprehensive Assessment of Right Whales Worldwide, 16-25 March, Cape Town, South Africa. 12pp. [Available from the Office of this Journal].

Schaeff, C.M., Best, P.B., Rowntree, V.J., Payne, R., Jarvis, C. and Portway, V.A. 1999. Dorsal skin color patterns among southern right whales (Eubalaena australis): Genetic basis and evolutionary significance. J. Hered. 90(4):464-71.

Schell, D.M. 1992. Stable isotope analysis of 1987-1991 zooplankton samples and bowhead whale tissues. Report for the Minerals Management Service. OCS Study MMS 92-0020 (unpublished). 101pp. [Available from the NTIS, Springfield, Virginia, 22161 as PB93-135879].

Schell, D.M., Saupe, S.M. and Haubenstock, N. 1989. Bowhead (Balaena mysticetus) growth and feeding as estimated by $\delta^{13} \mathrm{C}$ techniques. Mar. Biol. 103(4):433-43.

Taber, S. and Thomas, P. 1982. Calf development and mother-calf spatial relationships in southern right whale. Anim. Behav. 30:1072-83.

Thomas, P.O. 1988. Kelp gulls, Larus dominicanus, are parasites on flesh of the right whale, Eubalaena australis. Ethology 79(2):89-103.

Thomas, P.O. and Taber, S.M. 1984. Mother-infant interaction and behavioral development in southern right whales, Eubalaena australis. Behaviour 88(1-2):42-60.

Townsend, C.H. 1935. The distribution of certain whales as shown by logbook records of American whaleships. Zoologica (NY) 19(1-2):1-50+6 maps.

Whitehead, H.P. and Payne, R. 1981. New techniques for assessing populations of right whales without killing them. FAO Fish. Ser. (5) Mammals in the Seas:189-209.

Whitehead, H., Payne, R. and Payne, M. 1986. Population estimate for the right whales off Peninsula Valdes, Argentina, 1971-1976. Rep. int. Whal. Commn (special issue) 10:169-71. 